\title{
SYNTHESIS AND ANTIOXIDANT ACTIVITY STUDY OF NEW MANNICH BASES DERIVED FROM VANILLIC ACID
}

\author{
H. Hayun*, I. Gavrila, S. Silviana, A.E.K. Siahaan, R.F. Vonna \\ and M.I. Latifah \\ ${ }^{1}$ Faculty of Pharmacy, Universitas Indonesia, Depok, 16426, West Java, Indonesia. \\ *E-mail: hayun@farmasi.ui.ac.id
}

\begin{abstract}
We synthesized five new Mannich bases compounds from vanillic acid and evaluated for their antioxidant activities using a free-radical DPPH and FRAP methods. The compounds' structures were confirmed based on infrared, proton NMR, carbon NMR, and mass spectra. In this study, the compound 5-(pyrrolidin-1-ylmethyl)vanillic acid (2e) showed the best free-radical scavenger activity, while compound 2-[(diethylamino)methyl]vanillic acid (2c) showed the best as a ferric reductant. Mannich bases enhanced the free-radical scavenger activity but decreasing the ferric reduction potential of the parent compounds. The compounds were found to be moderate antioxidant agents.

Keywords: Vanillic Acid, Mannich Bases, Synthesis, Antioxidant, DPPH, FRAP.
\end{abstract}

(C) RASĀYAN. All rights reserved

\section{INTRODUCTION}

The excess of free radicals that are not neutralized by the human body's antioxidants defenses is believed as an inducing agent of the oxidative stress. It induced the damages of various species of biological molecules, which leads to some degenerative diseases, such as Alzheimer's, Parkinson's, atherosclerosis, cancer, arthritis, immunological incompetence, neurodegenerative disorders, and even aging. The unhealthy lifestyle, cigarette smoking, pollution, drugs, illness, stress, etc. compounded the risk of diseases due to that condition. On the other hand, food consumption, which rich in antioxidants such as fruits, vegetables, nuts, and the use of exogenous antioxidants as diet, plays an essential role in enhancing endogenous antioxidants for neutralizing the excess of the free radicals. ${ }^{1-4}$

Phenolic compounds are a major determinant of antioxidant potentials of foods. ${ }^{5}$ The compounds have one or more hydroxyl groups and range from simple to highly polymerized molecules. ${ }^{6}$ Vanillic acid is a natural phenolic, a class of para-hydroxybenzoic acid or paraben that has moderate antioxidant, antiinflammatory, and anticancer activity. ${ }^{7-9}$

Many aminoalkyl derivatives have been prepared using the Mannich reaction to develop more potent bioactive compounds. ${ }^{10-11}$ Some Mannich bases derived from phenol compounds, such as several chalcones, thymol, and flavanone, exhibited better antioxidant activity than the corresponding parent compounds. ${ }^{12-13}$ However, there was no report about the effect of Mannich bases substitutions on the biological activity of vanillic acid. To further understand that effect and to find new antioxidant agents, hence we synthesized the Mannich bases compounds from vanillic acid and tested their antioxidant activity.

\section{Material and General Procedures}

\section{EXPERIMENTAL}

We purchased solvents and chemicals from commercial sources (Sigma-Aldrich, USA; Merck, Germany; and Mallinckrodt, USA). Silica gel 60 (Merck, Germany) was used to column chromatography. The compounds' purity was tested using TLC-silica gel $60 \mathrm{GF}_{254}$ (Merck, Germany), while their melting points were measured using the Stuart ${ }^{\mathrm{TM}}$ melting point apparatus (Stuart Scientific, UK) and were uncorrected. 
FTIR-8400S Spectrophotometer (Shimadzu, Japan), NMR spectrometer (Agilent, USA) at $500 \mathrm{MHz}$ and $125 \mathrm{MHz}$ were used to record infrared, proton NMR and carbon NMR spectra respectively. $\mathrm{CDCl}_{3}$ or $\mathrm{CD}_{3} \mathrm{OD}$ was used as solvents. High-Resolution Mass Spectrometer (HR-MS) (LCT Premier XE, Waters, USA) in ESI mode was used to record mass spectra.

\section{Synthesis of Vanillic Acid (VA) (1)}

VA (1) was synthesized through vanillin oxidation using a mixture of sodium hydroxide and potassium hydroxide at high temperature as reported previously, with slight modification. ${ }^{14}$ Vanillin $(0.1 \mathrm{~mol})$ was added stepwise while stirring within $10-12$ min into a hot mixture $\left(160^{\circ} \mathrm{C}\right)$ of sodium hydroxide $(0.43$ mol), potassium hydroxide $(0.27 \mathrm{~mol})$ and $5 \mathrm{ml}$ of water in a stainless steel beaker. Initially, the temperature will rise to $180-195^{\circ} \mathrm{C}$ but then dropped to $150-160^{\circ} \mathrm{C}$ after stirring continuously. Water $(100 \mathrm{ml})$ was poured to dissolve the mixture, and then sulfur dioxide gas was flowed for $1 \mathrm{~min}$ and cooled to r.t. After that, hydrochloric acid $6 \mathrm{~N}(112 \mathrm{ml})$ was added to $\mathrm{pH} 3.2$ and cooled over an ice bath. The crystals formed were filtered and washed using cooled distilled water $(150 \mathrm{ml})$. The crystal then was dried in an oven vacuum at $50^{\circ} \mathrm{C}$ for $7 \mathrm{~h}$ to get $\mathbf{1}$.

\section{Synthesis of the Mannich Bases 2a-e}

The compounds (2a-e) were synthesized by the amino-alkylation of VA (1) through a Mannich reaction refers to the preparation of Mannich bases derivatives of curcumin analog and dehydrozingerone reported previously. ${ }^{15-16}$ A mixture of formaldehyde solution $(80 \mathrm{mmol})$ and corresponding secondary amines $(80$ mmol) was mixed with $18 \mathrm{~mL}$ solution of $1(20 \mathrm{mmol})$ in ethanol, heated under reflux at $\pm 50^{\circ} \mathrm{C}$ during $30 \mathrm{~min}$. It stirred until a completed reaction at $25^{\circ} \mathrm{C}$ for $12-24 \mathrm{~h}$ (TLC monitoring). The mixture then was refrigerated overnight, and the resulting precipitate was filtered and washed using cooled acetone. Recrystallization or column chromatography of crude product afforded pure compound 2a-e.

\section{In vitro Antioxidant Assay}

The antioxidant activities of synthesized compounds (2a-e) and vanillic acid evaluated spectrophotometrically following the procedure of free-radical DPPH scavenger and Ferric ion Reducing Activity Potential (FRAP) as reported previously, with slight modification. ${ }^{5,17-18}$ Quercetin was used as a standard.

\section{DPPH Free Radical Scavenger}

To a series of solutions contained six various concentrations of the test compounds or the standard in methanol, methanolic solution of 1,1-diphenyl-2-pycrylhydrazine (DPPH, $100 \mu \mathrm{g} / \mathrm{ml}$ ) was added. The mixtures were stirred and incubated at a darkened room temperature for $30 \mathrm{~min}$, and their absorbance was measured at $517 \mathrm{~nm}$ against the blank. The scavenging activity (\%) was calculated using a formula:

$\mathrm{Ac}=$ the absorbance of negative control

$$
\% \text { Scavenging }=\frac{(\mathrm{Ac}-\mathrm{At})}{\mathrm{At}} \times 100
$$

$\mathrm{At}=$ the absorbance with tested compound

The $\mathrm{IC}_{50}$ value of scavenging capacity was determined by plotting the scavenging activity (\%) versus concentration.

\section{Ferric Reduction Activity Potential (FRAP)}

The fresh FRAP reagent was prepared as reported by Hossain et al. ${ }^{5}$ To a series solution of various concentrations of the test compounds or the standard in methanol, the FRAP reagents were added, stirred and incubated at $37^{\circ} \mathrm{C}$ for $6 \mathrm{~min}$. The absorbance of the intense blue color of the ferrous tripyridyl-triazine complex (Fe2+-TPTZ) formed from the reduction of ferric tripyridyl-triazine complex (Fe3+-TPTZ) was measured at $595 \mathrm{~nm}$ against the blank. The percentage of a ferrous equivalent of the compound was calculated using a formula:

$$
\% \text { Ferrous equivalent }=\frac{(\text { Absorbance of test compound })}{\left(\begin{array}{c}
\text { Absorbance of } 1000 \mu \mathrm{M} \text { FeSO } \\
132
\end{array}\right.} \times 100
$$


The ferric reduction activity potential (FRAP) of the compounds expressed as the concentration needed to reduce $\mathrm{Fe}^{3+}$ to $\mathrm{Fe}^{2+}$ equivalent to $50 \%$ of $1000 \mu \mathrm{M} \mathrm{FeSO}_{4}\left(\mathrm{EC}_{50}\right)$ was calculated by plotting the \% ferrous equivalent against concentration.

\section{Physical and Spectral Data of The Synthesized Compounds Vanillic Acid (1)}

White-yellowish powder, $91.41 \%$ yield, $\mathrm{mp} 210-212^{\circ} \mathrm{C}$, Rf: $0.53, \lambda(\mathrm{MeOH}): 258.5 \mathrm{~nm}$ and $289 \mathrm{~nm}$. IR $\left(\mathrm{KBr}, \mathrm{cm}^{-1}\right): 3483(\mathrm{O}-\mathrm{H}$ carboxylates$), 3083-2750(\mathrm{O}-\mathrm{H}$ phenol), $1681(\mathrm{C}=\mathrm{O}$ carboxylates $), 1599$ and $1433\left(\mathrm{C}=\mathrm{C}\right.$ aromatic), 1456 and $1381\left(\mathrm{CH}_{3}\right), 1112$ (C-O eter), 1028 (C-O carboxylates), 918 and 761 (1,2,4-trisubstitution). ${ }^{1} \mathrm{H}-\mathrm{NMR}\left(\mathrm{CD}_{3} \mathrm{OD}, \delta \mathrm{ppm}\right): 7.56$ (d, $1 \mathrm{H}$ of $\left.\mathrm{H}-\mathrm{Ar}\right), 7.54$ (s, $1 \mathrm{H}$ of $\left.\mathrm{H}-\mathrm{Ar}\right), 6.83(\mathrm{~d}, 1 \mathrm{H}$ of $\mathrm{H}-\mathrm{Ar}), 3.87$ (s, $3 \mathrm{H}$ of $\left.-\mathrm{OCH}_{3}\right) \cdot{ }^{13} \mathrm{C}-\mathrm{NMR}\left(\mathrm{CD}_{3} \mathrm{OD}, \delta \mathrm{ppm}\right): 170.02(1 \mathrm{C}, \mathrm{C}=\mathrm{O}), 152.55\left(1 \mathrm{C}, \mathrm{COCH}_{3}\right.$ aromatic), 148.54 (1C, $\mathrm{C}-\mathrm{OH}$ aromatic), 125.24 (1C, aromatic), 122.94 (1C, aromatic), 115.77 (1C, aromatic), $113.69\left(1 \mathrm{C}\right.$, aromatic), $56.32\left(1 \mathrm{C},-\mathrm{O}-\mathrm{CH}_{3}\right)$.

\section{2-Methoxy-4,6-bis[(dimethylamino)methyl]phenol (2a)}

Brown viscous liquid, $18.23 \%$ yield, $\lambda_{\max }(\mathrm{MeOH}): 286 \mathrm{~nm}$. IR $\left(\mathrm{KBr}, \mathrm{cm}^{-1}\right): 1600$ and $1458(\mathrm{C}=\mathrm{C}$ aromatic), 1496 and 1363 (alkyl), $1153(\mathrm{C}-\mathrm{O}), 1087$ (C-N). ${ }^{1} \mathrm{H}-\mathrm{NMR}\left(\mathrm{CDCl}_{3}, \delta \mathrm{ppm}\right): 6.71$ (d, 1H of H$\mathrm{Ar}), 6.46(\mathrm{~d}, 1 \mathrm{H}$ of $\mathrm{H}-\mathrm{Ar}), 3.81$ (s, $3 \mathrm{H}$ of $\left.-\mathrm{OCH}_{3}, \mathrm{C}_{8}\right), 3.56\left(\mathrm{~s}, 2 \mathrm{H}\right.$ of $\left.\mathrm{Ar}-\mathrm{CH}_{2}-\mathrm{N}\right), 3.24$ (s, $2 \mathrm{H}$ of Ar- $\mathrm{CH}_{2}-$ $\mathrm{N}), 2.26$ (s, $6 \mathrm{H}$ of dimethylamine), and $2.16\left(\mathrm{~s}, 6 \mathrm{H}\right.$ of dimethylamine). ${ }^{13} \mathrm{C}-\mathrm{NMR}\left(\mathrm{CDCl}_{3}, \delta \mathrm{ppm}\right): 147.64$

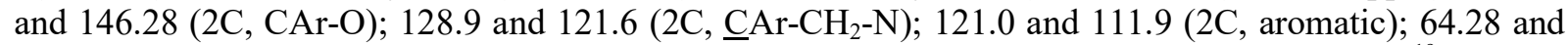
$62.59\left(2 \mathrm{C}, \mathrm{Ar}-\mathrm{CH}_{2}-\mathrm{N}\right) ; 55.90\left(1 \mathrm{C}, \mathrm{CH}_{3}-\mathrm{O}\right) ; 45.21$ and $44.48\left(4 \mathrm{C}, \mathrm{CH}_{3}-\mathrm{N}\right.$ of dimethylamine) ${ }^{19}$ HR-MS $(\mathrm{m} / \mathrm{z})$ observed $239.1760(\mathrm{M}+\mathrm{H})^{+}$, calcd. masses for $\mathrm{C}_{13} \mathrm{H}_{23} \mathrm{~N}_{2} \mathrm{O}_{2}: 239.1760$ (error $0.0 \mathrm{ppm}$ ).

\section{2-Methoxy-4,6-di [(morpholine-4-yl) methyl]phenol (2b)}

Brownish white powder, $40.68 \%$ yield, $\mathrm{mp} 110-111^{\circ} \mathrm{C}, \lambda_{\max }(\mathrm{MeOH}): 283.5 \mathrm{~nm}$. IR $\left(\mathrm{KBr}, \mathrm{cm}^{-1}\right): 2949$ and 2906 (C-H alkyl), 1597 and $1473(\mathrm{C}=\mathrm{C}$ aromatic), 1458 and 1365 (alkyl), 1155 (C-N) 1114 (C-O). ${ }^{1} \mathrm{H}-\mathrm{NMR}\left(\mathrm{CD}_{3} \mathrm{OD}, \delta \mathrm{ppm}\right): 6.68(\mathrm{~d}, 1 \mathrm{H}$ of $\mathrm{H}-\mathrm{Ar}), 6.89(\mathrm{~d}, 1 \mathrm{H}$, of $\mathrm{H}-\mathrm{Ar}), 3.40\left(\mathrm{~s}, 2 \mathrm{H}, \mathrm{CH}_{2}-\mathrm{N}\right.$ of morpholine), 3.67 ( $\mathrm{t}, 4 \mathrm{H}, \mathrm{O}-\mathrm{CH}_{2}$ of morpholine), 3.66 (s, $2 \mathrm{H}, \mathrm{CH}_{2}-\mathrm{N}$ of morpholine), 3.69 ( $\mathrm{t}, 4 \mathrm{H}, \mathrm{O}-\mathrm{CH}_{2}$ of morpholine), $3.83\left(\mathrm{~s}, 3 \mathrm{H}\right.$ of $\left.-\mathrm{OCH}_{3}\right), 2.43\left(\mathrm{t}, 4 \mathrm{H}, \mathrm{N}-\mathrm{CH}_{2}\right.$ of morpholine), and $2.52\left(\mathrm{t}, 4 \mathrm{H}, \mathrm{N}-\mathrm{CH}_{2}\right.$ of morpholine). ${ }^{13} \mathrm{C}-\mathrm{NMR}\left(\mathrm{CD}_{3} \mathrm{OD}, \delta \mathrm{ppm}\right): 124.14,113.69,128.74$ and 122.44 (4C, $\mathrm{CAr}$ ), 146.68 and $148.86\left(2 \mathrm{C}, \mathrm{C}_{\mathrm{Ar}}\right), 60.72\left(1 \mathrm{C}, \mathrm{CH}_{2}-\mathrm{N}\right.$ of morpholine), 54.06 (2C, $\mathrm{N}-\mathrm{CH}_{2}$ of morpholine), $67.63\left(2 \mathrm{C}, \mathrm{O}_{-} \mathrm{CH}_{2}\right.$ of morpholine, $), 64.19\left(1 \mathrm{C}, \mathrm{CH}_{2}-\mathrm{N}\right.$ of morpholine), $54.52\left(2 \mathrm{C}, \mathrm{N}^{-\mathrm{CH}_{2}}\right.$ of morpholine), $67.76\left(2 \mathrm{C}, \mathrm{O}-\mathrm{CH}_{2}\right.$ of morpholine), $56.45\left(1 \mathrm{C}, \mathrm{CH}_{3}-\mathrm{O}, \mathrm{C}_{23}\right) .{ }^{19} \mathrm{HR}-\mathrm{MS}(\mathrm{m} / \mathrm{z})$ obsserved $323.1978(\mathrm{M}+\mathrm{H})^{+}$, calcd masses for $\mathrm{C}_{17} \mathrm{H}_{27} \mathrm{~N}_{2} \mathrm{O}_{4}: 323.1892$ (error $2.2 \mathrm{ppm}$ ).

\section{3-[(Diethylamino)methyl]vanillic Acid (2c)}

Dark brown viscose liquid, $12.26 \%$ yield, $\lambda_{\max }(\mathrm{MeOH}): 253.5 \mathrm{~nm}$ and $289 \mathrm{~nm}$. IR $\left(\mathrm{KBr}, \mathrm{cm}^{-1}\right): 3583-$ $3017(\mathrm{O}-\mathrm{H}), 2974(\mathrm{C}-\mathrm{H}), 1564$ and $1390\left(\mathrm{COO}^{-}\right.$carboxylate), 1496 and $1284(\mathrm{C}=\mathrm{C}$ aromatic), 1458 and 1246 (alkyl), $1084(\mathrm{C}-\mathrm{N}) .{ }^{1} \mathrm{H}-\mathrm{NMR}\left(\mathrm{CD}_{3} \mathrm{OD}, \delta \mathrm{ppm}\right): 7.61$ (s, $1 \mathrm{H}$ of $\left.\mathrm{H}-\mathrm{Ar}\right), 7.53$ (d, 1H of 4.19 (s, 2H of $\left.\mathrm{Ar}-\mathrm{CH}_{2}-\mathrm{N}\right), 3.89\left(\mathrm{~s}, 3 \mathrm{H}\right.$ of $\left.-\mathrm{OCH}_{3}\right), 3.06\left(\mathrm{q}, 4 \mathrm{H},-\mathrm{CH}_{2}-\mathrm{N}\right.$ of diethylamine), and $1.30\left(\mathrm{t}, 6 \mathrm{H}, \mathrm{C}-\mathrm{CH}_{3}\right.$ of diethylamine). ${ }^{13} \mathrm{C}-\mathrm{NMR}\left(\mathrm{CD}_{3} \mathrm{OH}, \delta\right.$, ppm): $174.26(1 \mathrm{C}, \mathrm{C}=\mathrm{O}$ carboxylate $), 150.60$ and $148.51(2 \mathrm{C}, \mathrm{CAr}-$ $\mathrm{O}), 129.40,125.83,117.26$, and $114.46\left(4 \mathrm{C}, \mathrm{C}_{\mathrm{Ar}}\right), 56.45\left(1 \mathrm{C}, \mathrm{O}-\mathrm{CH}_{3}\right), 53.51\left(1 \mathrm{C}, \mathrm{Ar}-\mathrm{CH}_{2}-\mathrm{N}\right), 48.04$ (2C, $-\mathrm{CH}_{2}-\mathrm{N}$ of diethylamine), $9.72\left(2 \mathrm{C},-\mathrm{CH}_{3}\right.$ of diethylamine). ${ }^{19}$ HR-MS (m/z) observed 254.1392 $(\mathrm{M}+\mathrm{H})^{+}$, calcd masses for $\mathrm{C}_{13} \mathrm{H}_{20} \mathrm{NO}_{4}: 254.1314$ (error $0.03 \mathrm{ppm}$ ).

\section{5-[(4-Methylpiperazin-1yl)methyl]vanillic Acid (2d)}

Brownish white crystal needle, $36.58 \%$ yield, mp $127-129^{\circ} \mathrm{C}, \lambda_{\max }(\mathrm{MeOH}): 345.5 \mathrm{~nm}$. IR $\left(\mathrm{KBr}, \mathrm{cm}^{-1}\right)$ : 2974 - 2825, (C-H alkyl), 1608 and 1444 ( $\mathrm{COO}^{-}$anionic), 1564 and 1462 (C=C aromatic), 1494, and 1388 (alkyl), 1111 (C-O), and $1084(\mathrm{C}-\mathrm{N}) .{ }^{1} \mathrm{H}-\mathrm{NMR}\left(\mathrm{CD}_{3} \mathrm{OD}, \delta \mathrm{ppm}\right): 7.51$ (d, $1 \mathrm{H}$ of $\left.\mathrm{H}-\mathrm{Ar}\right), 7.45(\mathrm{~d}, 1 \mathrm{H}$ of $\mathrm{H}-\mathrm{Ar}), 3.88\left(\mathrm{~s}, 3 \mathrm{H}\right.$ of $\left.-\mathrm{OCH}_{3}\right), 3.79\left(\mathrm{~s}, 2 \mathrm{H}\right.$ of $\left.\mathrm{Ar}-\mathrm{CH}_{2}-\mathrm{N}\right), 2.71\left(\mathrm{~m}, 8 \mathrm{H},-\mathrm{CH}_{2}-\mathrm{N}-\mathrm{CH}_{2}\right.$ of piperazine), and 2.42 (s, $3 \mathrm{H}, \mathrm{N}-\mathrm{CH}_{3}$ of piperazine). ${ }^{13} \mathrm{C}-\mathrm{NMR}\left(\mathrm{CD}_{3} \mathrm{OD}, \delta \mathrm{ppm}\right): 174.02(1 \mathrm{C}, \mathrm{C}=\mathrm{O}$ carboxylate $), 150.16$ and 148.28 (2C, CAr-O), 128.22, 125.13, 121.51, and 113.48 (4C, CAr), $59.34\left(1 \mathrm{C}, \mathrm{OCH}_{3}\right), 56.43(1 \mathrm{C}$, 
RASĀYAN J.Chem.

Vol. 13 | No. 1 |131 - 138| January - March | 2020

Ar- $\left.\mathrm{CH}_{2}-\mathrm{N}\right), 55.20\left(2 \mathrm{C}, \mathrm{C}-\mathrm{N}\right.$ of piperazine), 52.44 (2C, C-N of piperazine), 45.27 (1C, N-CH $\mathrm{CH}_{3}$ of piperazine). ${ }^{19}$ HR-MS $\left(\mathrm{m} / \mathrm{z}\right.$ ) observed $281.1497(\mathrm{M}+\mathrm{H})^{+}$, calcd masses for $\mathrm{C}_{14} \mathrm{H}_{21} \mathrm{~N}_{2} \mathrm{O}_{4}: 281.1423$ (error $1.4 \mathrm{ppm})$.

\section{5-[(Pyrrolidin-1-yl)methyl]vanillic Acid (2e)}

Brownish granule, $31.19 \%$ yield; $\mathrm{mp} 195-198^{\circ} \mathrm{C}, \lambda_{\max }(\mathrm{MeOH}): 243.5 \mathrm{~nm}$. IR $\left(\mathrm{KBr}, \mathrm{cm}^{-1}\right): 3620-2904$ $(\mathrm{OH}), 1667$ (C=O carboxylate), 1456 (alkyl), $1113(\mathrm{C}-\mathrm{O}), 1088(\mathrm{CN}), 1028$ (C-OH carboxylic). ${ }^{1} \mathrm{H}-\mathrm{NMR}$ $\left(\mathrm{CD}_{3} \mathrm{OD}, \delta \mathrm{ppm}\right): 2.05$ (p, $4 \mathrm{H}, \mathrm{CH}_{2}$ of pirrolidne), $3.2\left(\mathrm{t}, 4 \mathrm{H}, \mathrm{N}-\mathrm{CH}_{2}\right.$ of pirrolidine), $3.89\left(\mathrm{~s}, 3 \mathrm{H}\right.$ of $\left.\mathrm{OCH}_{3}\right)$, 4.23 (s, $2 \mathrm{H}$ of $\left.\mathrm{Ar}-\mathrm{CH}_{2}-\mathrm{N}\right), 7.59 \mathrm{ppm}$ (d, $2 \mathrm{H}$ of $\left.\mathrm{HAr}\right) .{ }^{13} \mathrm{C}-\mathrm{NMR}(\mathrm{CD} 3 \mathrm{OH}, \delta \mathrm{ppm}): 24.04\left(2 \mathrm{C}, \mathrm{CH}_{2}\right.$ of pyrrolidine), 54.46 (2C, $\mathrm{CH}_{2}$ of pyrrolidine), 55.05 (1C, $\left.\mathrm{CH}_{2}-\mathrm{Ar}\right), 56.46\left(1 \mathrm{C}, \mathrm{CH}_{3}-\mathrm{O}-\mathrm{Ar}\right), 114.35,118.66$, 125.89 and 129.79 (4C, CAr), 148.41 and 149.96 (2C, CAr-O), 174.62 (1C, C=O carboxylate). ${ }^{19}$ HR-MS $(\mathrm{m} / \mathrm{z})$ observed $252.1238(\mathrm{M}+\mathrm{H})^{+}$, calcd masses for $\mathrm{C}_{13} \mathrm{H}_{18} \mathrm{NO}_{4}: 252.1157$ (error $0.8 \mathrm{ppm}$ ).

\section{Chemistry}

\section{RESULTS AND DISCUSSION}

Five new Mannich bases compounds from vanillic acid (2a-e) were synthesized successfully. The synthesis methods were summarized in Scheme-1. The substitutions of dimethylamine and morpholine Mannich bases were obtained di-Mannich bases of 2-methoxyphenol (2a-b), while the substitution of diethylamine, N-methylpiperazine, and pyrrolidine Mannich bases was obtained Mannich bases derivatives of vanillic acid (2c-e).<smiles>COc1cc(C(=O)c2ccc(C(C)C)cc2)ccc1O</smiles><smiles>[R2]c1cc([R2])c(O)c(OC)c1</smiles><smiles>[R]c1cc(C(=O)O)cc(OC)c1O</smiles>

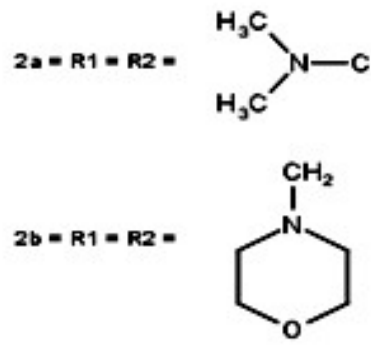<smiles>CCN(C)CC</smiles><smiles>CC1CCN(C)CC1</smiles>

Scheme-1: The Synthesis of Title Compounds

The disappearance of a sharp peak of $\mathrm{OH}$ phenolic in the infrared spectra of prepared compounds at 3483 $\mathrm{cm}^{-1}$ indicating hydrogen bonding formation between $\mathrm{OH}$ and $\mathrm{N}$ of the Mannich base. ${ }^{20}$ The bands at the range of 1084-1155 $\mathrm{cm}^{-1} 1$ conform to C-N, C-O phenol, and C-O ether. In the infrared spectra of $\mathbf{2 a}$ and 2b were observed the disappearance of the $\mathrm{C}=\mathrm{O}$ carboxylate peak at $1564-1667 \mathrm{~cm}^{-1}$ indicated the occurrence of decarboxylation. In ${ }^{1} \mathrm{H}-\mathrm{NMR}$ spectra, the only two remaining protons in the aromatic rings 
appeared as singlet or doublet peaks with $J=2-3 \mathrm{~Hz}$ in range of $\delta 6.46-7.56 \mathrm{ppm}$ indicated that the Mannich base group substituted a proton at the ortho position relative to the $\mathrm{OH}$ phenolic group of $\mathbf{1}$. In ${ }^{1} \mathrm{H}-\mathrm{NMR}$ spectra of 2a was appeared two singlet peaks equal to $6 \mathrm{H}$ of $\mathrm{N}_{-} \mathrm{CH}_{3}$ at 2.16 and $2.26 \mathrm{ppm}$ respectively, and two singlet peaks equivalent to $4 \mathrm{H}$ of $\mathrm{Ar}-\mathrm{CH}_{2}-\mathrm{N}$ at 3.24 and $3.56 \mathrm{ppm}$ respectively. While in 2b was appeared two triplet peaks from $4 \mathrm{H}$ of $\mathrm{N}_{-} \mathrm{CH}_{2}$ morpholine at 2.43 and $2.52 \mathrm{ppm}$ respectively, two triplet peaks from a $4 \mathrm{H}$ of $\mathrm{O}-\mathrm{CH}_{2}$ morpholine at 3.67 and $3.69 \mathrm{ppm}$, and two singlet peaks equivalent to $2 \mathrm{H}$ of $\mathrm{Ar}-\mathrm{CH}_{2}-\mathrm{N}$ at 3.40 and $3.66 \mathrm{ppm}$ respectively. The data indicated the occurrence of two substitutions of the Mannich base at ortho and para position relative to the hydroxyl group by replacing the $\mathrm{H}$ and carboxylic group respectively of $1 .{ }^{19}$ The structures supported by ${ }^{13} \mathrm{C}-\mathrm{NMR}$ spectra exhibited the disappearance of carbon of $\mathrm{C}=\mathrm{O}$ and expected number and types of carbons: aromatic and aliphatic moieties. This result was in line with the result of a Mannich reaction of vanillic acid (1) using diethylamine as secondary amine previously reported. ${ }^{21}$ However, our study showed that a Mannich reaction of 1 using diethylamine, 1-methylpiperazine, and pyrrolidine as secondary amine resulted in one Mannich base substitution at the ortho position relative to the hydroxyl group of $\mathbf{1}$ (compound 2c-e). The structures supported by ${ }^{13} \mathrm{C}$-NMR spectra exhibited the appearance of carbon of $\mathrm{C}=\mathrm{O}$ and expected number and types of carbons: aromatic and aliphatic moieties. All the structures of the synthesized compound were further supported by mass spectra, which provided the molecular masses of the compounds. These values were in complete conformity with the structure expected.

\section{Antioxidant Activity}

Figures- 1 and 2 presented the relation between concentrations of the title compounds and their ability as $\mathrm{DPPH}$ radical scavenger and ferric ion reductant. The activities were concentration-dependent. The $\mathrm{IC}_{50}$ or $\mathrm{EC}_{50}$ values of their activities were displayed in Table-1. The compounds 2a-e exhibited moderate to weak antioxidant activity compared to quercetin used as a standard. The $\mathrm{IC}_{50}$ values of radical scavenging activity were in the range of $26.55-651.16 \mu \mathrm{M}$. In this series, the compound 5-(pyrrolidin-1ylmethyl)vanillic acid (2e) showed the best free-radical scavenger activity. However, the activity was lower compared to quercetin $\left(\mathrm{IC}_{50}=6.84 \mu \mathrm{M}\right)$. The radical scavenger activities of the Mannich bases were higher than that of the vanillic acid $\left(\mathrm{IC}_{50}=11,608.65 \mu \mathrm{M}\right)$. These results were in line with several Mannich bases of phenolic compounds reported earlier. ${ }^{11-12}$

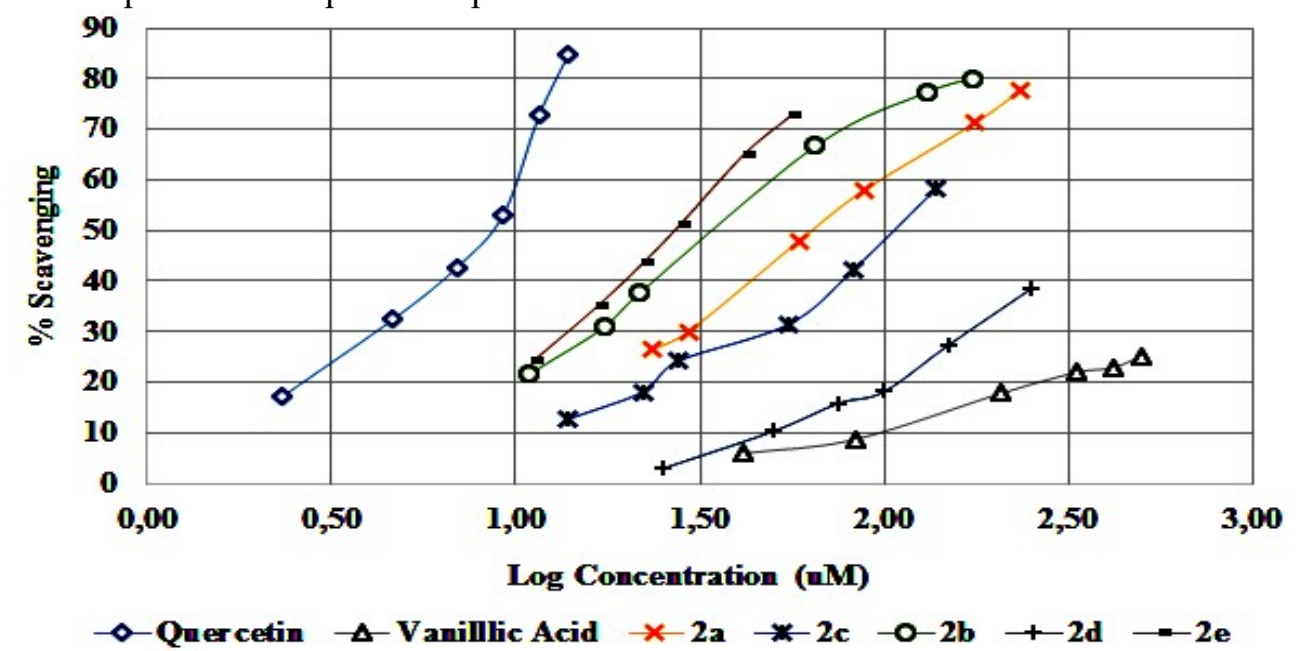

Fig.-1: The Concentrations and DPPH Radical Scavenging (\%) Curve of Synthesized Compounds

The electron-donating groups directly attached to the aromatic ring is one factor that can enhance free radical scavenger. ${ }^{22}$ The ferric reduction activity of synthesized compounds (2a-e) expressed as $\mathrm{EC}_{50}$ values were in the range of $17.67-60.65 \mu \mathrm{M}$. In this series, the compound 2[(diethylamino)methyl]vanillic acid (2c) showed the best ferric reductant activity. However, the activity was lower compared to quercetin used as a standard $\left(\mathrm{EC}_{50}=2.71 \mu \mathrm{M}\right)$. 
RASĀYAN J. Chem.

Vol. 13 | No. 1 |131 - 138| January - March | 2020

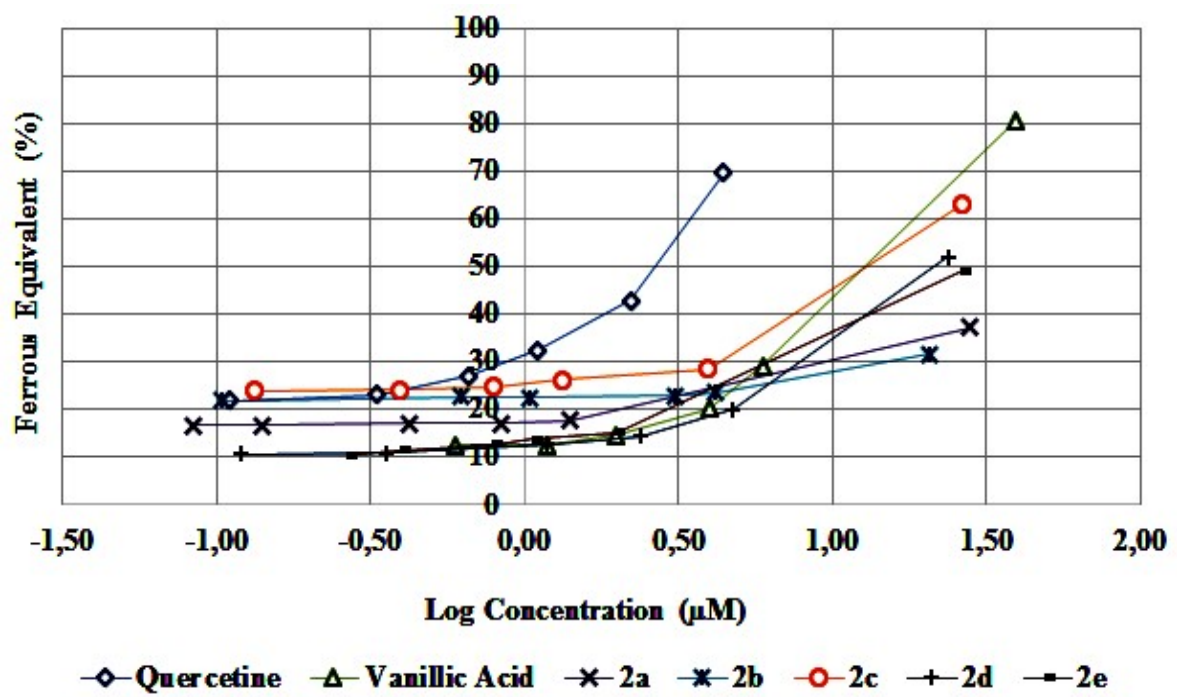

Fig.-2: The Concentrations and Ferrous Equivalent (\%) Curve of Synthesized Compounds

Table-1: Antioxidant Activity of Synthesized Compounds (2a-e)<smiles>[R]c1cc([R2])c(O)c(OC)c1</smiles>

\begin{tabular}{|c|c|c|c|c|}
\hline \multirow[b]{2}{*}{ Compound } & \multirow[b]{2}{*}{$\mathrm{R}_{1}$} & \multirow[b]{2}{*}{$\mathrm{R}_{2}$} & DPPH & $F R \triangle P$ \\
\hline & & & $\mathrm{IC}_{50}(\mu \mathrm{M})^{1)}$ & $\mathrm{EC}_{50}(\mu \mathrm{M})^{1)}$ \\
\hline 1 & $\mathrm{C}=\mathrm{O}(\mathrm{OH})$ & $\mathrm{H}$ & $11,608.65$ & 21.40 \\
\hline $2 \mathrm{a}$ & & & 66.87 & 45.10 \\
\hline $2 b$ & & & 38.33 & 60.65 \\
\hline $2 \mathrm{c}$ & $\mathrm{C}=\mathrm{O}(\mathrm{OH})$ & & 112.36 & 17.67 \\
\hline $2 d$ & $\mathrm{C}=\mathrm{O}(\mathrm{OH})$ & & 651.16 & 22.51 \\
\hline $2 \mathrm{e}$ & $\mathrm{C}=\mathrm{O}(\mathrm{OH})$ & & 26.55 & 22.09 \\
\hline \multicolumn{3}{|c|}{ Quercetin } & 6.84 & 2.71 \\
\hline
\end{tabular}

${ }^{(1)}$ mean of triplicate determinations

The ferric reduction activity potential of the Mannich bases was relatively the same or lower than that of vanillic acid $\left(\mathrm{EC}_{50}=21.40 \mu \mathrm{M}\right)$. This result was in agreement with the ferric reductant activity of the Mannich base of 1,3,4-oxadiazole reported earlier. ${ }^{23}$ The low ferric reducing activity of the compound may be caused by the method was unable to detect slowly-reacting phenolic compound. ${ }^{24}$ The Mannich 
base group was decreasing the reaction rate. The antioxidant characteristics of phenolic compounds supported by the data showed that the compounds were more active as a radical scavenger than as ferric reducing agent. ${ }^{25}$

\section{CONCLUSION}

Five new Mannich base compounds derived from vanillic acid were prepared successfully. The compound 5-(pyrrolidin-1-ylmethyl)vanillic acid (2e) showed the best free-radical scavenger activity, while compound 2-[(diethylamino)methyl]vanillic acid (2c) showed the best as a ferric reductant. Mannich bases enhance the free-radical scavenger activity but decreasing the ferric reduction potential of the parent compounds. The compounds were found to be moderate antioxidant agents.

\section{ACKNOWLEDGMENT}

This work was funded by Universitas Indonesia, Depok, Indonesia (Research Grant, No.: 1768/UN2.R3.1/HKP.05.00/2018).Thanks to the Chemistry Department, Bandung Institute of Technology (ITB), Indonesia, for providing a recording of NMR and mass spectra.

\section{REFERENCES}

1. J. Manivannan, T. Silambarasan, J. Shanthakumar, N. Suganya and S. Kanchana, 2016, Role of Antioxidants in Human Health. In: M. Hegde, A. Zanwar, S. Adekar (Eds), Omega-3 Fatty Acids, Springer International Publishing, Switzerland, pp. 501-512, DOI: 10.1007/978-3-319-40458-5

2. Z. Huyut, F. Beydemir and E. Gülçin, Biochemistry Research International, ID 7616791, 10 pages, (2017), DOI: $10.1155 / 2017 / 7616791$

3. K.K. Kattappagari, C.S.R. Teja, R.K. Kommalapati, C. Poosarla, S.R. Gontu and B.V. Reddy, Journal of Orofacial Sciences, 7, 71 (2015), DOI: 10.4103/0975-8844.169745

4. A. Yadav, R. Kumari, A. Yadav, J.P. Mishra, S. Srivatva and S. Prabha, Research in Environment and Life Sciences, 9(11), 1328 (2016).

5. M.B. Hossain, A.B. Martin-Diana, N.P. Brunton, C. Barry-Ryan, and M. Wilkinson, Rasayan Journal of Chemistry, 1(4), 751(2008).

6. N. Balasundram, K. Sundram and S. Samman, Food Chemistry, 99, 191(2006), DOI: 10.1016/j.foodchem.2005.07.042

7. R. Manuja, S. Sachdeva, A. Jain and J. Chaudhary, International Journal of Pharmaceutical Sciences Review and Research, 22(2), 109(2013).

8. P.S.M. Prince, S. Rajakumar and K. Dhanasekar, European Journal of Pharmacology, 668, 233 (2011), DOI: 10.1016/j.ejphar.2011.06.053

9. A. Vinoth and R. Kowsalya, Journal of Cancer Research and Therapy, 4(6), 1285 (2018), DOI: 10.4103/0973-1482.191057

10. P.S. Misra, P. Shanmugasundaram, R. Chaudhary and M.V. Aanandhi, Rasayan Journal of Chemistry, 3(1), 51(2010).

11. J. Untung, I. Iskandarsyah and H. Hayun, Molbank, 2017, M949(2017), DOI:10.3390/M949

12. G. Roman, European Journal of Medicinal Chemistry, 89, 743(2015), DOI: 10.1016/j.ejmech.2014.10.076

13. B.P. Bandgar, S.A. Patil, R.N. Gacche, B.L. Korbad, B.S. Hote, S.N. Kinkar, S.S. Jalde, Bioorganic \& Medicinal Chemistry Letters, 20(2), 730 (2010), DOI: 10.1016/j.bmcl.2009.11.068

14. I.A. Pearl, Organic Syntheses, 30, 101(2003), DOI: 10.15227/orgsyn.030.0101

15. T. N. Putri, A. Bachtiar and H. Hayun, Journal of Applied Pharmaceutical Sciences, 8(5), 19(2018), DOI: $10.7324 /$ JAPS.2018.8503

16. H. Hayun, A. Arrahman, E.M. Purwati, A. Yanuar, F. Fortunata, F. Suhargo, D.W. Syafiqah, C. Ignacia, A.R. Novalia, Journal of Young Pharmacist, 10(2), Suppl s6(2018), DOI: 10.5530/jyp.2018.2s.6

17. O. Atolani, C.B. Adeosun, A.P. Oluyori and J. Olota, Rasayan Journal of Chemistry, 12(3), 1052 (2019), DOI: 10.31788/RJC.2019.1235122

18. T. M. Siregar, E. Budianto, H. Cahyana and W. Wibowo, Rasayan Journal of Chemistry, 11(4), 1765 (2018), DOI:10.31788/RJC.2018.1143051 
19. R.M. Silverstein, F.X. Webster, D.J. Kiemle, Spectrometric Identification of Organic Compounds, 7th ed., John Wiley \& Sons, Inc., New York, NY, USA (2005).

20. C. Dank, S. Felsinger, B. Kirchknopf, M. Mastalir, H. Kählig, A. Roller et al., Molecules, 20, 1686 (2015), DOI:10.3390/molecules20011686

21. H. Mikawa, K. Sato and C. Takasaki, Bulletin of the Chemical Society of Japan, 29(2), 259 (1956), DOI: $10.1246 /$ bcsj.29.259

22. L.V.B. Hoelz, B.A.C. Horta, J.Q. Araújo, M. Albuquerque, R.B. de Alencastro and J.F.M. da Silva, Journal of Chemistry and Pharmaceutical Research, 2(5), 291(2010).

23. L. Ma, Y. Xiao, C. Li, Z.L. Xie, D.D. Li, Y.T. Wang, H.T.Ma, H.L. Zhu, M.H. Wang,Y.H. Ye, Bioorganic \& Medicinal Chemistry, 21(21), 6763 (2013), DOI: 10.1016/j.bmc.2013.08.002

24. S. Dontha, Asian Journal of Pharmaceutical and Clinical Research, 9 (Suppl. 2), 14(2016). DOI: 10.22159/ajpcr.2016.v9s2.13092

25. J.N. Veljković, A.N. Pavlović, S.S. Mitić, S.B. Tošić, G.S. Stojanović, B.M. Kaličanin, D.M. Stanković, M.B. Stojković, M.N. Mitić, J.M. Brcanović, Journal of Food and Nutrition Research, 52 (1), 12(2013).

[RJC-5300/2019] 